\title{
CAREER CHALLENGES MODEL AMONG FEMALE ENGINEERS: PLS-SEM ANALYSIS
}

\author{
Ummu Sakinah S, Ridzwan CR, Ramlee M and Zaliza H \\ Faculty of Technical and Vocational, Universiti Pendidikan Sultan Idris, 35900 Tanjong Malim, Perak. Malaysia. \\ *Corresponding author: Ummu Sakinah S, \\ Email address: usakinah.msubri@yahoo.com
}

\begin{abstract}
Women are likely to leave the job sector as a result of the crisis between their commitments to the career with the household interest. In response to this issue, this study aims to build a career challenge model that caters to the demand among women in this century. Hence, this study has identified the key factors to the challenges faced by female engineers in pursuing their career as an engineer through the Delphi Modified Technique. The result shows this study looking into the relationship between four independent constructs namely, life balance, childcare, leaves and gender discrimination. Meanwhile, the dependent construct of this study is career challenges faced by women. The scope of the study comprises female engineers with families and 211 respondents were selected to answer the questionnaire. The data obtained were analysed using the PLS-SEM 2.0 software via the algorithm, bootstrapping and blindfolding method. The construction process of this model involves two tests including the construction of the measurement model and the structure model. Testing the measurement model involves internal consistency namely (a) convergent validity and (b) discriminant validity in which these two validities have six analyses; (i) external loading, (ii) composite reliability, (iii) average variance extracted (AVE), (iv) Fornell-Larcker, (v) cross loading, and (vi) Heterotrait-Monotrait Ratio (HTMT). Meanwhile, the structural model testing involves the analysis of (i) Multicollinearity (Inner VIF), (ii) Path Coefficient, (iii) $R$ square $\left(R^{2}\right)$, (iv) size effect $\left(f^{2}\right)$, and (v) Predictive Relevance $\left(Q^{2}\right)$. The findings indicate that gender discrimination and life balance have significant relationships in influencing career challenges. Hence, this model is expected to contribute to the literature of Human Resource Management.
\end{abstract}

Keywords: Career challenges, life balance, female engineers, PLS-SEM

\section{INTRODUCTION}

The role of women in the career sector provides the economy with a fresh air especially for lowincome families who live in rural areas as it can help to improve the economic standard of the families and the local communities. However, it is inevitable for women to deal with challenges and obstacles as part of their strive to master their career. This might be stressful to their mental immunity particularly to married women $^{1,2}$. In this regard, women tend to leave the job sector upon experiencing a crisis of personal commitment in the household. Furthermore, 2016 recorded a decrease in the number of women aged 25 years to 64 years who are involved in the employment sector ${ }^{3}$. This suggests that female engineers are more likely to quit their work after marriage as the responsibility of managing the family is to be prioritized especially after having children ${ }^{4}$. Therefore, it is not surprising that women participation in engineering is low as compared to the number of female student enrolments in engineering institutions. Hence, a career model for women of this century needs to be built $t^{5,6}$.

\section{LITERATURE REVIEW}

Career pattern as an engineer plays an important role in attracting longitudinal participation among women. Hence, this study has identified the key factors to the challenges faced by female engineers in pursuing their career as an engineer through the Delphi Modified Technique. The first challenge is the conflict of balancing their lives which happens when fair responsibility is difficult to be implemented due to the demand in both their professional and personal lives. The concept of work-life balance describes the ideal condition of splitting one's time, energy and commitment between career and other important aspects of their personal life, including families ${ }^{7}$. Work-life balance is also an important issue in the engineering industry from the perspectives of both organizational effectiveness as well as career health ${ }^{8}$. The main factors that lead to limited work-life balance are lengthy working time and tight schedule which subsequently limit the engineers' personal time? Moreover, construction engineering workers have limited leniency in managing their working hours as well as frequent work trips as compared to those in other industries ${ }^{7}$. Thus, work patterns with limited flexible working hours and intense job responsibilities will affect the balance of their lives.

The second challenge is the child care issue where the comfort and safety of the child is a priority. The recent increase in the number of child abuse cases is worrying among parents for them to place their child under the care of outsiders. Childcare is a complex issue as it involves the security and suitability of a nursing home as well as the lack of experience among 
the caretakers ${ }^{10}$. Limited flexibility in childcare timing also complicates things for mothers (female engineers) to manage the delivery and pick up of their children ${ }^{11}$. Additionally, childcare centres that are situated outside the working area also makes it difficult for them to breastfeed their babies ${ }^{12}$. Such impression on the lack of proper care centres causes female engineers to quit their work willingly in order to take care of their children at home ${ }^{13}$. Childcare facilities that suit the situation and needs of female engineers have limited flexibility in its timing, location and inexperienced caretakers.

The next challenge is leave approval. In reality, most employees have the responsibility to support their family including their husband, wife, children, or elderly parents. Being a child, a wife, and a mother, women tend to take leave to care for sick family members ${ }^{14}$ which leads to the likeliness for them to take more leaves than men. However, most employers tend to disapprove employee leave applications that are submitted at the very last minute to protect their interest in discipline and work participation ${ }^{15}$. Furthermore, women also tend to take maternity leave for them to have adequate rest and recovery after delivery ${ }^{16,17}$. In this regard, statistic shows that $36 \%$ of female employees in the technical fields are not entitled to proper maternity leave ${ }^{18}$. This is because there are employers who believe that the success rate of a project highly depends on engineers' long working hours as opposed to their leaves ${ }^{19}$. In addition, work patterns that require engineers' commitment to work on weekends also affect their difficulty of obtaining leaves ${ }^{20}$. Hence, the difficulty for leave approval also affects women's emotions and mentality to perform dual responsibilities in their household as well as their career.

Gender discrimination in engineering is also a challenge for women to continue working. There are still perceptions in the industry that favours males over females and argues the competency of female workers in high risk fields of work ${ }^{21,22,23}$. Despite their enthusiasm to prove their competency and skills, female engineers are often doubted by their male co-workers and certain employers as well as being resorted to their extreme sympathy when it comes to doing heavy works $22,24,25$. As a consequence, female engineers are less likely to be asked to conduct risky tasks which results in reduced income as the salary ladder often depends on the scope of work as well as the level of risks. Furthermore, gender discrimination not only affects the scope of an engineer's career but also offers different wages and pay rates according to gender ${ }^{25,26}$. This is because the scope of duties for female engineers is usually different from male engineers who are often perceived to have better competency, which then affects their level of income ${ }^{27,28}$. In conclusion, gender discrimination poses a challenge for women to increase employers' confidence in their ability to carry out major tasks for the sake of having equality in their wages and pay rates. Therefore, this model is necessary to guide attentionrelated parties in order to help female engineers continue working.

\section{METHODOLOGY}

This study was conducted on 211 female engineers in Malaysia who have their own families. The demographic information for the 211 respondents is shown in Table 1. The questionnaire was developed and adapted from previous studies ${ }^{17,23,27}$ and was verified by seven experts in the field of engineering and career.

Table 1 : Respondent Demographic Information

\begin{tabular}{lcc}
\hline $\begin{array}{l}\text { Demographic } \\
\text { Information }\end{array}$ & $\begin{array}{c}\text { Number of } \\
\text { Respondents }(\mathrm{n})\end{array}$ & Percent (\%) \\
\hline Status: Married & 211 & 100 \\
Position: Civil & 211 & 100 \\
Engineering & & \\
Age (year) & 61 & 28.9 \\
$<30$ & 76 & 36.3 \\
$30-34$ & 60 & 28.4 \\
$35-39$ & 14 & 6.5 \\
$40-44$ & 0 & 0.0 \\
$>44$ & 18 & 8.5 \\
Number of Children & 0 year (person) \\
0 & 59 & 27.9 \\
1 & 72 & 34.3 \\
2 & 62 & 29.4 \\
3 & 0 & 0.0 \\
$>3$ & 69 & 32.8 \\
Work Experience (year) & & \\
$<6$ & 78 & 36.8 \\
$6-10$ & 56 & 26.4 \\
$11-15$ & 8 & 4.0 \\
$>15$ & & \\
\hline
\end{tabular}

The data obtained were analysed using the PLSSEM 2.0 software via the algorithm, bootstrapping and blindfolding method. Structural equation modeling (SEM) - partial least squares (PLS) (PLS-SEM). Testing the Confirmatory Factor Analysis (CFA) measurement or testing model is the first step in the data analysis procedure that uses the PLS-Path Modeling approach. The measurement model is conducted to determine how far the items measure what should be measured, its accuracy in representing a construct and fulfilling the standards of validity and reliability. Testing the measurement model is a procedure that should be conducted in most studies 29,30 . It involves internal consistencies of (a) convergent validity and (b) discriminant validity. The aspect of convergence validity can be seen at the values of (i) outer loading, (ii) composite reliability, and (iii) average variance extracted (AVE). While discriminant validity can be seen in (i) FornellLarcker, (ii) cross loading, and (iii) Heterotrait- 
Monotrait Ratio (HTMT) $)^{31}$. The researcher uses the algorithm method in the PLS-SEM software. The next step is to evaluate the structure model. Assessment of the structural model should be based on several analyses and this process directly tests the hypotheses of the study. Structural model testing involves the analysis of (i) internal VIF or Multicollinearity (Inner VIF), (ii) structural model coefficient (T), (iii) determination coefficient ( $R$ square, $R^{2}$ ), (iv) size effect $\left(f^{2}\right)$, and $(v)$ predictive relevance $\left(Q^{2}\right)^{30}$. For this value analysis, the researcher uses bootstrapping and blindfolding methods in the PLS-SEM software.

\section{RESULTS}

Testing of measurement model. Measuring Convergent Validity. The aspect of convergence validity can be seen at the value of (i) outer loading, (ii) composite reliability, and (iii) average variance extracted (AVE). External load or outer loading is the standard load that connects the factor to the indicator variable. Since the data is automatically standardized in the SmartPLS, the load value varies between 0.00 and 1.00 . The loading should be significant as larger loads indicate a more robust and reliable measurement model.

The load is also regarded as a form of item reliability coefficient for a reflective model where a closer value of 1.0 is more reliable than the latent variable. Therefore, the load value should be $>0.7029$. However, any load values within the range of 0.50 to 0.70 should be considered if the value of AVE is $>0.500^{30,32}$.

Composite reliability is an alternative to Cronbach's alpha as a convergent validity test in a reflective model. Past studies use composite reliability in PLS research as a measure of reliability because Cronbach's alpha further underestimates the reliability of the scale and the reliability of the composites can lead to higher estimates of real reliability. The composite reliability may be equal to or $>0.60$ 29,30; equal to or $>0.70$ for a model aimed at authentication $^{31}$.

Furthermore, the AVE can also be used as a test of convergent and differentiated legitimacy. It reflects the average community for every latent factor in a reflective model. In a reproductive model, the AVE should be $>0.50^{30,31}$ and greater than the cross load. This means that the factor should explain at least half of the variation of each indicator. AVE that is $<0.50$ means that the error variance is beyond the variation described. The reliability of the indicator can be interpreted as the square measure of measurement, in which $0.708=0.50{ }^{30}$. Therefore, the reliability of AVE should be $>0.50$.
In the early stage of the convergent legality analysis involving the independent constructs with the career challenge construct, the AVE value does not meet the requirement where the value of the life balance, leave and gender discrimination constructs were $<0.50$ (refer Table 2 ). Hence, items with an outside load value of $<0.50$ in each construct needs to be eliminated to increase the AVE value to $>0.50{ }^{30}$. Table 2 shows the items in the constructs that need to be eliminated, including three items in the life balance construct (B2, B8, and B10), one item in the leave construct (L19) and two items in the gender discrimination construct (G25 and G26). Such elimination of items is necessary for the convergence validity requirements to be fulfilled.

Table 2: Outer Loading Value, Composite Reliability (CR) and AVE

\begin{tabular}{|c|c|c|c|c|}
\hline Construct & Item & $\begin{array}{c}\text { Outer } \\
\text { loading } \\
>0.50\end{array}$ & $\begin{array}{c}\text { CR } \\
>0.70\end{array}$ & $\begin{array}{c}\text { AVE } \\
>0.50\end{array}$ \\
\hline Life Balance & $\begin{array}{l}\text { B1 } \\
\text { B2 } \\
\text { B3 } \\
\text { B4 } \\
\text { B5 } \\
\text { B6 } \\
\text { B7 } \\
\text { B8 } \\
\text { B9 } \\
\text { B10 } \\
\text { B11 } \\
\text { B12 }\end{array}$ & $\begin{array}{l}0.698 \\
0.032 \\
0.761 \\
0.720 \\
0.684 \\
0.763 \\
0.656 \\
0.209 \\
0.701 \\
0.222 \\
0.745 \\
0.669\end{array}$ & 0.865 & 0.388 \\
\hline Childcare & $\begin{array}{l}\text { C13 } \\
\text { C14 } \\
\text { C15 } \\
\text { C16 } \\
\text { C17 } \\
\text { C18 }\end{array}$ & $\begin{array}{l}0.730 \\
0.859 \\
0.553 \\
0.764 \\
0.699 \\
0.849\end{array}$ & 0.883 & 0.562 \\
\hline Leave & $\begin{array}{l}\text { L19 } \\
\text { L20 } \\
\text { L21 } \\
\text { L22 } \\
\text { L23 }\end{array}$ & $\begin{array}{l}0.360 \\
0.786 \\
0.810 \\
0.521 \\
0.834\end{array}$ & 0.807 & 0.474 \\
\hline $\begin{array}{l}\text { Gender } \\
\text { Discrimination }\end{array}$ & $\begin{array}{l}\text { G24 } \\
\text { G25 } \\
\text { G26 } \\
\text { G27 } \\
\text { G28 } \\
\text { G29 }\end{array}$ & $\begin{array}{l}0.601 \\
0.417 \\
0.269 \\
0.864 \\
0.792 \\
0.831\end{array}$ & 0.811 & 0.445 \\
\hline
\end{tabular}

Once the items are eliminated, Table 3 shows that all external loading values, composite reliability and AVE for each construct have fulfilled the required conditions of the load value $>0.50$, composite reliability $>0.70$ and AVE $>0.50$.

Table 3 also shows that the loading value is less than 0.70 . However, all AVE values above 0.50 are still acceptable $e^{30,31}$. Therefore, the findings show that the instrument has fulfilled the criteria of convergent validity. 
Table 3: Outer Loading Value, Composite Reliability and AVE

\begin{tabular}{|c|c|c|c|c|}
\hline Construct & Item & $\begin{array}{c}\text { Outer } \\
\text { loading } \\
>0.50\end{array}$ & $\begin{array}{c}C R \\
>0.70\end{array}$ & $\begin{array}{c}\text { AVE } \\
>0.50\end{array}$ \\
\hline \multirow[t]{9}{*}{ Life Balance } & B1 & 0.704 & \multirow[t]{9}{*}{0.904} & \multirow[t]{9}{*}{0.511} \\
\hline & B3 & 0.764 & & \\
\hline & B4 & 0.722 & & \\
\hline & B5 & 0.683 & & \\
\hline & B6 & 0.765 & & \\
\hline & B7 & 0.659 & & \\
\hline & B9 & 0.705 & & \\
\hline & B11 & 0.746 & & \\
\hline & B12 & 0.676 & & \\
\hline \multirow{6}{*}{ Childcare } & C13 & 0.732 & \multirow[t]{6}{*}{0.885} & \multirow[t]{6}{*}{0.565} \\
\hline & C14 & 0.858 & & \\
\hline & C15 & 0.564 & & \\
\hline & C16 & 0.769 & & \\
\hline & C17 & 0.703 & & \\
\hline & C18 & 0.846 & & \\
\hline \multirow[t]{4}{*}{ Leave } & $\mathrm{L} 20$ & 0.803 & \multirow[t]{4}{*}{0.884} & \multirow[t]{4}{*}{0.583} \\
\hline & L21 & 0.836 & & \\
\hline & L22 & 0.532 & & \\
\hline & L23 & 0.839 & & \\
\hline Gender & G24 & 0.559 & \multirow[t]{4}{*}{0.874} & \multirow[t]{4}{*}{0.642} \\
\hline \multirow[t]{3}{*}{ Discrimination } & G27 & 0.910 & & \\
\hline & G28 & 0.809 & & \\
\hline & G29 & 0.879 & & \\
\hline
\end{tabular}

Measuring Discriminant Validity Numbers. Discriminant validity is based on the (i) FornellLarcker, (ii) cross loading, and (iii) HeterotraitMonotrait (HTMT) ratio. By referring to the Fornell-Larcker criteria, AVE values may also be used to prove discriminant validity ${ }^{32}$. The criterion of the Fornell-Larcker posits for each

variable is that the primary value of AVE should be higher than its correlation with other variables. This means that for each variable, the variance shared with the indicator block is greater than the variance divided by the other variables. In the output of SmartPLS in the Fornell-Larcker criterion table, the main value of AVE appears inside diagonal cells and the correlation appears below it. Therefore, in absolute terms, if the top number (which is the prime value of the AVE) in any factor column is higher than the number (correlation) below,

then there is a discriminant validity. Table 4 shows that all the major AVE values for each construct are higher than the constructs below. This value proves that Fornell Larcker's criteria are met.

Table 4 - Fornell Lacker (AVE > R)

\begin{tabular}{lcccc}
\hline Construct & $\begin{array}{c}\text { Life } \\
\text { Balance }\end{array}$ & Childcare & Leave & $\begin{array}{c}\text { Gender } \\
\text { Disc. }\end{array}$ \\
\hline Life Balance & 0.715 & & & \\
Childcare & 0.064 & 0.752 & & \\
Leave & 0.314 & 0.052 & 0.801 & \\
Gender & 0.072 & -0.062 & 0.108 & 0.763 \\
Discrimination & & & & \\
\hline
\end{tabular}

Cross loading or crosslinking is a good loading indicator for the intended factors and other factors that are not intended to be clearly measured. The determinant for loading factor is $>0.70{ }^{31}$ but it can still be between 0.50 to 0.70 29. While the determinant for cross loading should be $<0.30^{31}$ or $<0.40^{29}$.

Cross loading is also declared as an alternative to AVE. Hence, if the cross loading value is not eligible, it is still acceptable if the AVE value meets the requirements ${ }^{30}$. Table 5 shows that all cross loading values are $<0.40$ which reach the criteria of cross loading.

Table 5: Cross Loading

\begin{tabular}{lcccc}
\hline Item & $\begin{array}{c}\text { Life } \\
\text { Balance }\end{array}$ & Childcare & $\begin{array}{c}\text { Gender } \\
\text { Discrimination }\end{array}$ & Leave \\
\hline B1 & 0.704 & 0.006 & 0.220 & -0.001 \\
B3 & 0.764 & 0.003 & 0.195 & 0.166 \\
B4 & 0.722 & 0.071 & 0.207 & 0.006 \\
B5 & 0.683 & -0.036 & 0.219 & 0.136 \\
B6 & 0.765 & 0.006 & 0.247 & 0.044 \\
B7 & 0.659 & 0.075 & 0.107 & 0.014 \\
B9 & 0.705 & 0.107 & 0.315 & 0.038 \\
B11 & 0.746 & 0.043 & 0.190 & 0.047 \\
B12 & 0.676 & 0.145 & 0.307 & 0.002 \\
C13 & 0.035 & 0.732 & 0.047 & 0.029 \\
C14 & 0.095 & 0.858 & 0.035 & -0.080 \\
C15 & -0.074 & 0.564 & 0.045 & 0.035 \\
C16 & 0.004 & 0.769 & 0.005 & -0.116 \\
C17 & -0.002 & 0.703 & 0.068 & 0.013 \\
C18 & 0.054 & 0.846 & 0.047 & -0.081 \\
G24 & 0.266 & -0.034 & 0.559 & 0.036 \\
G27 & 0.263 & 0.071 & 0.910 & 0.099 \\
G28 & 0.254 & 0.040 & 0.809 & 0.120 \\
G29 & 0.223 & 0.079 & 0.879 & 0.084 \\
L20 & 0.066 & -0.060 & 0.166 & 0.803 \\
L21 & 0.077 & 0.007 & 0.004 & 0.836 \\
L22 & 0.061 & -0.074 & 0.047 & 0.532 \\
L23 & -0.001 & -0.076 & 0.091 & 0.839 \\
\hline
\end{tabular}

HTMT ratio is the geometric mean value for the Heterotrait-Monotrait correlation (correlation indicator across different phenomena) divided by the average correlation of Heterotrait-Monotrait (correlation indicator in the same construction). Average geometric mean use is required because there are two monotrait-heteromethod (set correlation in construction) due to the existence of two constructs ${ }^{31}$. In the appropriate model, the Heterotrait correlation should be smaller than the Monotrait correlation where the HTMT ratio should be $<1.00^{31}$. If the value of HTMT is less than 0.90 , the validity of discrimination has existed between the constructs of the built-in reflective model ${ }^{30}$. The value of HeterotraitMonotrait (HTMT) ratio should be $<0.9032$. Hence, the Heterotrait-Monotrait (HTMT) ratio in this study has been achieved with all values being $<1.00$ as illustrated in Table 6 . 
Table 6: Heterotrait-Monotrait (HTMT)

\begin{tabular}{lcccc}
\hline Construct & $\begin{array}{c}\text { Life } \\
\text { Balance }\end{array}$ & Childcare & Leave & $\begin{array}{c}\text { Gender } \\
\text { Disc. }\end{array}$ \\
\hline $\begin{array}{l}\text { Life Balance } \\
\text { Childcare }\end{array}$ & 0.106 & & & \\
Leave & 0.377 & 0.096 & & \\
$\begin{array}{l}\text { Gender } \\
\text { Discrimination }\end{array}$ & 0.117 & 0.122 & 0.147 & \\
\hline
\end{tabular}

Testing of structural models in PLS-SEM. As explained, the evaluation of the structural model should be based on several analyses and this process directly tests the hypotheses of the study. Structural model testing involves the analysis of (i) internal VIF or Multicollinearity (Inner VIF), (ii) structural model coefficient (B), (iii) determination coefficient (R square, $R^{2}$ ), (iv) size effect $\left(f^{2}\right)$, and $(v)$ predictive relevance, $Q^{2}$ [30].

Multicollinearity (Inner VIF). Multicollinearity test is conducted to determine whether the independent variables are redundant to one another [31]. Collinearity is said to exist in the case of VIF $<5.00{ }^{30}$. The results of multicollinearity analysis in this study are presented in Table 7 which shows that all VIF test values are $<5.00$. Therefore, each variable has met the appropriate VIF criteria.

Table 7: Inner VIF

\begin{tabular}{lc}
\hline Construct & Career Challenges \\
\hline Life Balance & 1.115 \\
Childcare & 1.010 \\
Gender Discrimination & 1.120 \\
Leave & 1.019 \\
\hline
\end{tabular}

Path Coefficients. B indicates the expected variation in the dependent variable with a single variable variation unit ${ }^{30}$. The $B$ value of each route in the hypothesis model is calculated; the greater the value of $B$, the more significant the impact on endogenous latent construction. However, the $B$ values need to be verified for their significance through the T-statistical tests where T value should exceed 1.645 for one tailed study. In order to test the importance of path coefficients and T-statistics, a bootstrapping procedure is performed. Table 8 shows that the life balance construct has the highest path coefficient of $B=0.891$ as compared to other extracts.

Meanwhile, the predicted hypotheses of this study are (i) Ho1, the life balance factor has significant relationship in affecting career challenges, (ii) $\mathrm{Ho2}$, the childcare factor has significant relationship in affecting career challenges, (iii) Ho3, gender discrimination has significant relationship in influencing career challenges, and (iv) Ho4, the leave factor has significant relationship in affecting career challenges. As predicted, the results of the study in Table 8 show that only $\mathrm{Ho} 1$ and $\mathrm{Ho} 3$ are accepted which confirms that the gender discrimination and life balance factors have significant relationship in affecting career challenges, with $\mathrm{p}=0.00<0.05$ whereas $\mathrm{Ho} 2$ and Ho4 have no significant relationship in affecting career challenges, with $p>0.05$.

Table 8: Path Coefficient

\begin{tabular}{lcccc}
\hline Hypothesis & $\begin{array}{c}\text { Mean/ } \\
\text { Beta }\end{array}$ & $\begin{array}{c}\text { Standard } \\
\text { Deviation }\end{array}$ & $\begin{array}{c}\text { STDEV } \\
\text { STDE }\end{array}$ & $\begin{array}{c}\text { P Values } \\
<0.05\end{array}$ \\
\hline Ho1 & 0.810 & 0.053 & 15.969 & 0.000 \\
Ho2 & 0.138 & 0.081 & 1.691 & 0.492 \\
Ho3 & 0.279 & 0.047 & 6.243 & 0.000 \\
Ho4 & 0.104 & 0.059 & 1.730 & 0.084 \\
\hline
\end{tabular}

$R$ square $\left(R^{2}\right)$. The contribution value of all variables can be seen through the $R$ square $\left(R^{2}\right)$ values. The value of $R^{2}>0.67$ is strong, $R 2>0.33$ is moderate and $R^{2}>0.19$ is weak ${ }^{29}$. The result shows that the model of this study has a strong predictive power value of $R^{2}=0.994$ where the value of free extract contribution is high as illustrated in Table 9. This means that the $\mathrm{R}^{2}$ value suggests that $99.4 \%$ variants can be explained by the independent constructs towards the dependent construct of the research.

Table 9: $R$ Square $\left(R^{2}\right)$

\begin{tabular}{lc}
\hline Variable & $\mathbf{R}^{2}$ \\
\hline Career Challenges & 0.994 \\
\hline
\end{tabular}

The effect size $\left(\mathrm{f}^{2}\right)$ is determined by the value of $R$ Square $\left(R^{2}\right)$. The purpose of evaluating the effect of size $\left(f^{2}\right)$ is to see the dependency impact of a variable towards the other variables $^{30,31}$. When an independent variable is removed from the path of the model, it will alter the value of the determinant coefficient $\left(R^{2}\right)$ and defines whether the formation of exogenous latent has a significant effect on the value of the latent endogenous construct. The calculation of the size effects towards the variables is based on the following formula:

$$
f^{2}=\frac{\left(R^{2} \text { included }-R^{2} \text { excluded }\right)}{\left(1-R^{2} \text { included }\right)}
$$

The size effects can also be evaluated in three sizes, where $0.00 \leq f^{2}<0.15$ is small, $0.15 \leq f^{2}<$ 0.35 is moderate and $f^{2} \geq 0.35$ is large. Therefore, the analysis result in Table 10 shows that life balance and gender discrimination have a strong impact, with the value of $f^{2} \geq 0.35$. Meanwhile, child care and leave have a moderate effect of $f^{2}=0.333$ and $f^{2}=0.167(0.15$ $\leq \mathrm{f}^{2}<0.35$ ). 
Table 10: Size Effects $\left(f^{2}\right)$

\begin{tabular}{lcccc}
\hline $\begin{array}{l}\text { Factor } \\
\text { (exogenous) }\end{array}$ & Endogenous & $\begin{array}{c}\mathbf{R}^{2} \\
\text { included excluded }\end{array}$ & $\mathbf{f}^{\mathbf{2}}$ \\
\hline Life Balance & $\begin{array}{c}\text { Career } \\
\text { Challenges } \\
\text { Career }\end{array}$ & 0.994 & 0.982 & 2.000 \\
Childcare & $\begin{array}{c}\text { Callenges } \\
\text { Career }\end{array}$ & 0.994 & 0.992 & 0.333 \\
$\begin{array}{l}\text { Gender } \\
\begin{array}{l}\text { Discrimination } \\
\text { Leave }\end{array}\end{array}$ & $\begin{array}{c}\text { Challenges } \\
\text { Career } \\
\text { Challenges }\end{array}$ & 0.994 & 0.970 & 4.000 \\
\hline
\end{tabular}

Predictive relevance $\left(Q^{2}\right)$. This study uses the blindfolding method to obtain the predictive relevance $\left(Q^{2}\right)$ value. The measured $Q^{2}$ value must be greater than zero for specific endogenous latent construction ${ }^{29}$. Therefore, the blindfolding analysis result in Table 11 shows that $Q^{2}=0.161$ and this value meets the $Q^{2}$ criteria of $Q^{2}>0{ }^{29,30}$. Such value proves that the built model has a predictive relevance. Figure 1 shows the structural model of the career challenges model that has been developed.

\section{Table 11 - Predictive Relevance $\left(Q^{2}\right)$}

\begin{tabular}{lccc}
\hline $\begin{array}{l}\text { Dependent } \\
\text { Variable }\end{array}$ & SSO & SSE & $\mathrm{Q}^{2}=(1-$ SSE/SSO) \\
\hline $\begin{array}{l}\text { Career } \\
\text { Challenges }\end{array}$ & $5,829.00$ & $4,887.64$ & 0.161 \\
\hline
\end{tabular}

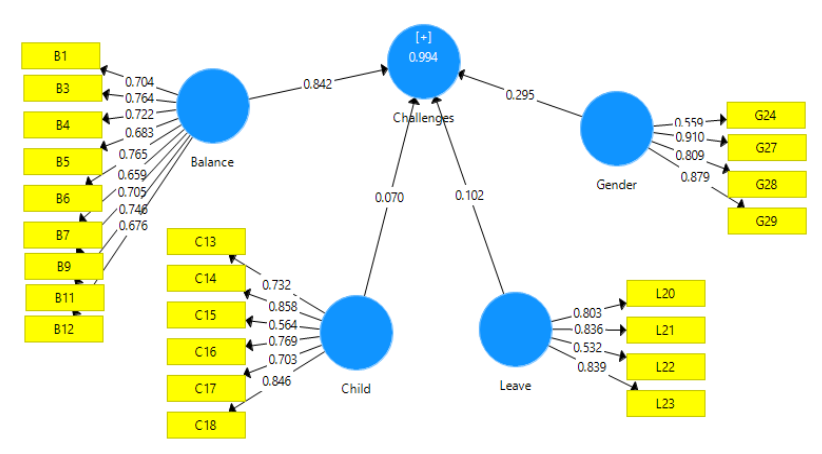

Figure 1: Career Challenges Model

\section{DISCUSSION}

The development of the career challenges model for female engineers who are married and have their own families indicates that this model has a predictive viability. This study finds that life balance and gender discrimination have significant relationships in influencing career challenges. This supported previous studies ${ }^{33,34}$ which report that life balance affects career challenges among women. Other studies ${ }^{35,36}$ also explain that discrimination against women affects their career challenges.

\section{CONCLUSION}

One of the main goals of the Human Resource Management (HRM) is to improve organizational performance. Along with the need to build a new career model ${ }^{5,6}$, this model is hoped to contribute to the literature in HRM. Apart from adding to the pool of knowledge, this model demonstrates that career challenges for female engineers can be conceptualized according to four important factors: childcare, leave, gender discrimination and life-balance conflict.

To expand this model, further research is proposed to explore new factors that contribute to the challenge of life balance among women in various fields so that a perfect life-balance model can be developed specifically for women.

\section{ACKNOWLEDGEMENTS}

We thank to our experts for this research; Prof. Madya Dr. Husna Johari, Mrs. Nor'ain Senin, Mrs. Farehan Mohamad, Mrs. Nur Aimi Rahim, Mrs. Nahiyatul Nazarah Ismail, Mrs. Rosmawati Johari, and Mrs. Nurshamshinazzatulbalqish Saminal.

\section{REFERENCES}

1. Halim, R. A., \& Aziz, N. N. A. Malaysian Female Graduates: Marriage, Motherhood and Labour Force Participation. International Journal of Multidisciplinary Research and Development 2016; 3(1): 109-114.

2. Minister Department, P. Economic Transformation Programme Annual Report 2011: 1-264.

3. Jabatan Tenaga Manusia. Pelan Strategik Jabatan Tenaga Manusia 2016-2020. Kementerian Sumber Manusia 2016: 1-64.

4. Fouad, N. A., Chang, W. H., Wan, M. et al. Women's Reasons for Leaving the Engineering Field. Frontiers Psychologist 2012; vol. 8.

5. Appelbaum, E., Boushey, H., \& Schmitt, J. The Economic Importance of Women's Rising Hours of Work: Time to Update Employment Standards. Center for American Progress and the Center for Economic and Policy Research, 2014 (April): 1-34. Retrieved from

https://cdn.americanprogress.org/wpcontent/uploads/2014/04/WomensRisingW orkv2.pdf

6. Noor Rahamah $\mathrm{Hj}$ Abu Bakar. Masa Kerja Fleksibel dalam Sektor Formal di Bandar: Mengimbangi Kerjaya dan Tanggungjawab Keluarga. Akademika 2013; 83(1): 77-80.

7. Lyness, K. S., \& Judiesch, M. K. Gender Egalitarianism and Work-Life Balance for Managers: Multisource Perspectives in 36 Countries. Applied Psychology 2014; 63(1): 96-129. 
8. Lingard, H. Francis, V., \& Turner, M. Worklife strategies in the Australian construction industry: implementation issues in a dynamic project-based work environment. International Journal of Project Management 2012; 30(3): 282-295.

9. Malone, E. K., \& Issa, R. R. A. Work-Life Balance and Organizational Commitment of Women in the U.S. Construction Industry. Journal of Professional Issues in Engineering Education and Practice 2012; 139(2): 87-98

10. Linnan, L., Arandia, G., Bateman, L. A., et al. The Health and Working Conditions of Women Employed in Child Care. International Journal of Environmental Research and Public Health 2017; 14(3): 214

11. Charitable, R. A Model for Predicting a Career Success in Engineering among Women and African American Men. The Sciences and Engineering 2012.

12. Madara, D. S., \& Cherotich, S.Challenges Faced by Female Students in EngineeringEducation. Journalof Education and Practice 2016; 7(25): 8-22.

13. Hibel, L. C., Trumbell, J. M., \& Mercado, E. Work/non-workday Differences in Mother, Child and Mother-Child Morning Cortisol in a Sample of Working Mothers and Their Children. Early Human Development 2014; 90(1): 1-7.

14. Ministry of Education. National Education Statistic: Higher Education Sector. Ministry of Education, Malaysia 2014.

15. Avais, M. A., Wassan, A. A., \& Shah, S. A Case Study on Problems of Working Women in City Sukkur. Academic Research International 2014; 5(2): 325-333.

16. Barati, A., Arab, R. O., \& Masoumi, S. S. Challenges and Problems Faced By Women Workers in India. Chroncile of the Neville Wadia Institute of Management Studies and Research 2014: 76-82. Retrieved from http: / / www.nevillewadia.com/images/Cro nicle2015/Azadeh-Barati15.pdf

17. Mittal, M. S., Sharma, M. S., \& Srivastava, P. P. Challenges Faced By Working Women at Workplace, Family and Society-Major Issues, Impact and Remedial Measures. 2015; 8(5): 64-77.

18. McDowall A. Workplace solutions for childcare In Community, Work \& Family. 2012; 15(2), 252-253.
19. Silim, A., \& Crosse, C. Women in Engineering (Reports): Fixing the Talent Pipeline. September, 22, 2014: 1-22.

20. Boushey, H., \& Glynn, S. J. The Effects of Paid Family and Medical Leave on Employment Stability and Economic Security. Center for American Progress 2012. April: 1-30.

21. Ellemers, N. Women at Work: How Organizational Features Impact Career Development. Behavioral and Brain Sciences 2014; 1(1): 46-54.

22. Abele, E. A., Spurk, D., \& Volmer, J. The Construct of Career Success: Measurement Issues and an Empirical Example. ZAF (2011); 43:195-206.

23. Vaganay, A., Canónico, E., \& Courtin, E. (2016). Challenges of Work-Life Balance Faced By Working Families: Reports Review.

24. Kaewsri, N., \& Tongthong, T. Professional Development of Female Engineers in the Thai Construction Industry. Procedia Social and Behavioral Sciences 2013; 88(1): 291-298.

25. Kyriakidou, 0 . Negotiating Gendered Identities through the Process of Identity Construction: Women Managers in Engineering. Equality, Diversity and Inclusion. An International Journal 2011; 31(1): 4-9.

26. Hatmaker, D. M. Practicing Engineers: Professional Identity Construction through Role Configuration. Journal Engineering Studies 2012; 2(2): 121-144.

27. Kaewsri, N., \& Tongthong, T. Favorable Female Attributes In Relation To Career Challenges Of Women Engineers In The Thai Construction Industry. International Journal of Construction Education and Research 2014; 10 (3): 222-236.

28. Azhar, S., \& Griffin, M. K. A.Women in construction: successes, challenges and opportunities - A USACE Case Study. 50th ASC Annual International Conference Proceedings 2014: 1-8.

29. Hair, J.F., Hult, G.T.M., Ringle, C.M. and Sarstedt, M. A Primer on Partial Least Squares Structural Equation Modeling (PLSSEM). Sage, Thousand Oaks 2014.

30. Henseler, J., Ringle, C. M., \& Sarstedt, M. A New Criterion for Assessing Discriminant Validity in Variance-Based Structural 
Equation Modeling. Journal of the Academy of Marketing Science 2015; 43(1): 115-135.

31. Ramayah, T., Cheah, J., Chuah, F., et al. Partial least squares structural equation modeling (PLS-SEM) using SmartPLS 3.0: An updated and practical guide to statistical analysis. (2nd edition) Singapore: Pearson 2018.

32. Fornell, C., \& Larcker, D. F. Evaluating Structural Equation Models with Unobservable Variables and Measurement Error. Journal of Marketing Research 1981; 18(1): 39-50.

33. Schueller-Weidekamm, C., \& KautzkyWiller, A. Challenges of Work-Life Balance for Women Physicians/Mothers Working In Leadership Positions. Gender Medicine 2012; 9(4): 244-250.

34. Shiva, G. A Study on Work Family Balance and Challenges Faced By Working Women. Journal of Business and Management 2013 (IOSR-JBM); 14(5): 1-4.

35. Michailidis, M. P., Morphitou, R. N., \& Theophylatou, I. Women at Workequality versus Inequality: Barriers for Advancing In the Workplace. International Journal of Human Resource Management 2012; 23(20): 4231-4245.

36. Hirsh, E. \& Lyons, C. J. Perceiving Discrimination on the Job: Legal Consciousness, Workplace Context and the Construction of Discrimination. Law and Society Review 2010; 44(2): 269-298. 